\title{
PULMONARY DIFFUSING CAPACITY AND ITS SUBDIVISIONS IN POLYCYTHEMIA VERA
}

\author{
By J. H. BURGESS * AND J. M. BISHOP
}

(From the Department of Medicine, University of Birmingham, Queen Elizabeth Hospital, Birmingham, England)

(Submitted for publication July 23, 1962; accepted February 28, 1963)

Polycythemia vera is characterized by a greatly increased red cell mass, and patients with the disease have an increase of both hemoglobin concentration and total blood volume. The purpose of the present study was to observe the effect of these two variables, and their changes with treatment, on pulmonary diffusion.

The rate of chemical reaction with hemoglobin is an important factor in the over-all rate of gas uptake from the lung. Roughton and Forster (1) proposed the equation $1 / D_{L}=1 / D_{M}+1 / \theta V C$ (Equation 1) and showed that by its use it was possible to subdivide the total diffusing capacity of the lung. $D_{L}$ is the total pulmonary diffusing capacity for $\mathrm{CO}$ from the alveolus to the interior of the red cell. $D_{M}$ is the membrane diffusing capacity and relates to the movement of gas from the alveolus to the surface of the red cell. $\theta$, often referred to as the rate of uptake of CO by the red cells, is actually the product of the rate at which $\mathrm{CO}$ replaces $\mathrm{O}_{2}$ in oxyhemoglobin and the concentration of hemoglobin (2). $V c$ is the pulmonary capillary blood volume at any instant. McNeill, Rankin, and Forster (3) have related these parameters in terms of resistances. $1 / D_{L}$ may be considered as the total resistance to gas uptake, which is composed of the sum of $1 / D_{M}$, the membrane resistance, and $1 / \theta V c$, the red cell resistance.

In polycythemia vera one would expect the increased hemoglobin concentration to result in an increase in $\theta$, thus lowering the red cell resistance and so producing an increase in $D_{L}$. Previous observers, however, have not found an abnormally high $D_{L}$ in this disease.

* Part of this work was done while holding a Nuffield Dominion Traveling Fellowship in medicine and part was supported by a fellowship from the Endowment Research Fund of the United Birmingham Hospitals. Present address: Montreal General Hospital, Montreal, Canada.
Harrop and Heath (4) in 1927, using Krogh's original $\mathrm{CO}$ technique, reported a subnormal diffusing capacity in seven patients with polycythemia vera; further measurements in one patient after treatment showed no significant change. There have since been several reports stating that $\mathrm{CO}$ uptake is normal, but none has given values for $D_{L}$ or compared pre- and posttreatment results. Ratto, Briscoe, Morton, and Comroe (5) reported a normal $\mathrm{CO}$ uptake in four patients. Rankin, McNeill, and Forster (6), and Forster (7), briefly mentioned that $D_{L}, D_{M}$, and $V c$ were normal in polycythemia vera. Fishman (8), quoting work from his laboratory with a steady state $\mathrm{CO}$ technique, concluded that diffusion was normal. Newman, Feltman, and Devlin (9) report a normal A-a (alveolar to arterial) difference for oxygen in four out of five patients with polycythemia vera.

People acclimatized to high altitude show features similar to polycythemia vera, as they have both an increased red cell mass and total blood volume (10). Barcroft and his colleagues (11) in 1920 measured $D_{L}$ by Krogh's technique and found slightly but not significantly higher values for 13 newly acclimatized subjects, as compared with values at sea level. They noted that the natives permanently resident at high altitudes had significantly higher values for $D_{L}$ than those of the party.

There have been several studies of $\mathrm{O}_{2}$ transfer in the lungs in acclimatized subjects. Houston and Riley (12) found a decrease in the A-a difference in $\mathrm{O}_{2}$ tension under conditions of prolonged simulated altitude and calculated that the $D_{L}$ for $\mathrm{O}_{2}$ was increased. Velasquez (13) reported that the maximal $D_{L}$ for $\mathrm{O}_{2}$ during exercise was greater than normal in subjects acclimatized to an altitude of $4,540 \mathrm{~m}$.

The plan of the present study was to measure 
$D_{L}, D_{M}$, and $V c$ in ten patients with polycythemia vera $a$ ) before treatment when both hemoglobin concentration and total circulating blood volume were abnormally high, $b$ ) 1 week later following several venesections when hemoglobin concentration was approximately normal, but blood volume usually still raised, and $c$ ) at least 3 months after treatment with $\mathrm{P}^{32}$ when both hemoglobin concentration and blood volume were close to normal.

\section{METHODS}

Ten patients were studied, in all of whom the diagnosis of polycythemia vera was established on clinical and hematological grounds and with the confirmatory evidence of pulmonary function tests. There were eight men and two women, ranging in age from 45 to 66 years.

Patient 6 had essential hypertension, and Patient 10 had a history of mild chronic bronchitis. Patient 8 had had a pulmonary infarction one month previously, but no other patient gave a history or had clinical or radiological evidence suggestive of such an event. The remainder had no history of cardiopulmonary disease, and physical examination, chest $\mathrm{X}$ ray, and electrocardiogram were normal. The spleen was palpably enlarged in all except Patient 9.

Each patient was studied before treatment and again 1 week later, after three or four venesections of about $500 \mathrm{ml}$ each. The third occasion of study was from 3 to 9 months (mean 5) after treatment with $\mathrm{P}^{32}$. $\mathrm{Pa}$ tient 4 died of gastrointestinal hemorrhage before the effect of $\mathrm{P}^{32}$ could be observed.

$D_{L}$ was measured in the sitting position by the singlebreath method, as modified by Ogilvie, Forster, Blakemore, and Morton (14). This was repeated three times at each of three different alveolar $\mathrm{O}_{2}$ tensions in order to calculate $D_{M}$ and $V c$. Alveolar $\mathrm{O}_{2}$ tensions of approximately 100 and $400 \mathrm{~mm} \mathrm{Hg}$ were obtained by having the patient inspire approximately $0.3 \% \mathrm{CO}, 8 \% \mathrm{He}$ in air or $0.3 \% \mathrm{CO}, 8 \% \mathrm{He}$ in $\mathrm{O}_{2}$. A third level of alveolar $\mathrm{O}_{2}$ tension of approximately $600 \mathrm{~mm} \mathrm{Hg}$ was achieved when the patient inspired the latter mixture after having breathed $\mathrm{O}_{2}$ for the previous 2 minutes.

Breath-holding times were kept close to 10 seconds (range 9 to 11) and were measured by the method of Jones and Meade (15). This consists of measuring from the beginning of inspiration to the mid-point of expiration and subtracting 0.3 of the inspiratory time to allow for diffusion occurring over these two periods. In the patients studied the use of this technique gave values for $D_{L}$ that differed little from those obtained by the more normal method of measuring breath-holding time. Residual volume was measured separately by a closed circuit $\mathrm{He}$ technique (16). Inspired volume was near maximum and kept as constant as possible for a given patient. The variation of alveolar volume from one stage of the study to another was never more than $400 \mathrm{ml}$, except in Patient 1 , in whom the mean values in the second and third studies differed by $1,200 \mathrm{ml}$.

The expired samples were collected after $1 \mathrm{~L}$ of expired air had washed out the dead space. The sample was then dried by passage over calcium chloride and analyzed for $\mathrm{CO}$ in an infrared analyzer. The instrument gave different readings for $\mathrm{CO}$ in air and $\mathrm{CO}$ in $\mathrm{O}_{2}$, so that separate calibration curves were used for the two circumstances. The sample then passed through a $\mathrm{CO}_{2}$ absorber and was analyzed for $\mathrm{He}$ with a katharometer. Absorption of $\mathrm{CO}_{2}$ was complete as judged by a zero deflection of the katharometer when gas mixtures containing no $\mathrm{He}$ were similarly treated. This instrument was also calibrated for different $\mathrm{O}_{2}$ tensions, and the absorbed $\mathrm{CO}_{2}$, which on the basis of previous experiments was assumed to be $4 \%$, was allowed for in the final calculation of percentage of $\mathrm{He}$. Expired $\mathrm{O}_{2}$ tensions were measured polarographically with a polythene-covered platinum electrode (17).

An allowance was made for back pressure of $\mathrm{CO}$, which was measured by a rebreathing technique (3). This was done at the start of the series and again after each three measurements of $D_{L}$. The value for a single $D_{L}$ estimate was interpolated and proportioned to the $\mathrm{O}_{2}$ tension of the sample. This back pressure estimate was then subtracted from both the initial and final $\mathrm{CO}$ concentrations.

Expired $\mathrm{O}_{2}$ tension was converted to the intracapillary $\mathrm{O}_{2}$ tension by allowing for the A-a difference for $\mathrm{O}_{2}$ as described by McNeill and associates (3). An assumed $\mathrm{O}_{2}$ uptake of $250 \mathrm{ml}$ per minute was divided by $1.23 \times D_{L}$ to give the $\mathrm{O}_{2}$ tension difference from alveolus to mean pulmonary capillary. This value was subtracted from the mean alveolar $\mathrm{O}_{2}$ tension, the latter being taken as $5 \mathrm{~mm}$ $\mathrm{Hg}$ greater than that of the expired sample.

$D_{M}$ and $V c$ were obtained from the graphical solution of Equation 1. Values for $\theta$ were taken from the data of Roughton and Forster (1), assuming $\lambda=2.5$. As these values for $\theta$ were derived for blood of normal $\mathrm{O}$. capacity (or hemoglobin concentration), a correction had to be applied in the case of polycythemic blood. This could be done either by changing $\theta$ in direct proportion to the $\mathrm{O}_{2}$ capacity (2), or by calculating $D_{M}$ and $V c$ using $\theta$ as given and then multiplying calculated $V c$ by $20 / \mathrm{O}_{2}$ capacity of patient's blood at the time of study (18). The latter method is simpler in practice and gives the same result as the former.

This correction for $V c$ assumes that the hemoglobin concentration of pulmonary capillary blood is the same as that of peripheral venous blood. If pulmonary capillary hematocrit is less than peripheral venous, $V c$ will be underestimated by a proportionate amount. It is also assumed that the rate of uptake of $\mathrm{CO}$ by the individual red cells is normal in polycythemia vera.

Physiological dead space and A-a $\mathrm{O}_{2}$ tension difference were measured in the supine position by using techniques described elsewhere, and values were compared with normal values at comparable age (19). Lung volumes, expiratory flow rates, and the FEV 1.0/FVC ratio (forced expiratory volume at 1 second as a percentage 
TABLE I

Details of patients and results of pulmonary function tests before treatment

\begin{tabular}{|c|c|c|c|c|c|c|c|c|c|c|c|c|c|}
\hline \multirow[b]{2}{*}{ Patient } & \multirow[b]{2}{*}{ Sex } & \multirow[b]{2}{*}{ Age } & \multirow[b]{2}{*}{ Height } & \multirow[b]{2}{*}{ Weight } & \multirow[b]{2}{*}{ BSA } & \multirow[b]{2}{*}{ VC* } & \multirow[b]{2}{*}{$\mathrm{RV}$} & \multirow[b]{2}{*}{ TLC } & \multirow[b]{2}{*}{ MEFR† } & \multirow[b]{2}{*}{$\underset{\text { FVC }}{\text { FEV }_{1.0 /}}$} & \multirow{2}{*}{$\underset{\text { nation }}{\stackrel{\mathrm{N}_{2}}{\text { Elimi- }}}$} & \multicolumn{2}{|c|}{$\mathrm{O}_{2}$ Saturation } \\
\hline & & & & & & & & & & & & Rest & $\begin{array}{l}\text { Exer- } \\
\text { cise }\end{array}$ \\
\hline 1 & $\mathbf{M}$ & $\begin{array}{c}y r s \\
53\end{array}$ & $\begin{array}{l}c m \\
174\end{array}$ & $\begin{array}{c}\mathrm{kg} \\
79\end{array}$ & $\begin{array}{c}m^{2} \\
1.95\end{array}$ & $\begin{array}{c}L \\
3.30 \\
(76)\end{array}$ & $\begin{array}{c}L \\
1.25 \\
(57)\end{array}$ & $\begin{array}{c}L \\
4.55 \\
(69)\end{array}$ & $\underset{278}{L / \min }$ & $\begin{array}{l}\% \\
82\end{array}$ & 2.8 & $\begin{array}{c}\% \\
96.0\end{array}$ & $\begin{array}{c}\% \\
96.2\end{array}$ \\
\hline 2 & $\mathbf{M}$ & 58 & 160 & 72 & 1.74 & $\begin{array}{l}3.80 \\
(109)\end{array}$ & $\begin{array}{c}1.90 \\
(93)\end{array}$ & $\begin{array}{c}5.70 \\
(101)\end{array}$ & 312 & 92 & 2.3 & 98.6 & 95.6 \\
\hline 3 & $\mathbf{M}$ & 64 & 183 & 59 & 1.74 & $\begin{array}{c}4.25 \\
(94)\end{array}$ & $\begin{array}{l}2.36 \\
(107)\end{array}$ & $\begin{array}{c}6.61 \\
(89)\end{array}$ & 193 & 72 & 1.5 & 96.2 & 95.9 \\
\hline 4 & $\mathbf{M}$ & 60 & 173 & 02 & 1.73 & $\begin{array}{c}3.52 \\
(85)\end{array}$ & $\begin{array}{r}2.14 \\
(80)\end{array}$ & $\begin{array}{c}5.66 \\
(90)\end{array}$ & 179 & 69 & 2.9 & 95.6 & 96.1 \\
\hline 5 & $\mathbf{M}$ & 45 & 167 & 55.5 & 1.63 & $\begin{array}{l}4.18 \\
(101)\end{array}$ & $\begin{array}{c}2.27 \\
(95)\end{array}$ & $\begin{array}{l}6.45 \\
(103)\end{array}$ & 271 & 78 & 2.0 & 96.6 & 94.1 \\
\hline 6 & $\mathbf{M}$ & 66 & 175 & 75.5 & 1.90 & $\begin{array}{c}3.57 \\
(119)\end{array}$ & $\begin{array}{c}2.85 \\
(93)\end{array}$ & $\begin{array}{c}6.42 \\
(94)\end{array}$ & 180 & 70 & 2.8 & 97.9 & 98.1 \\
\hline 7 & $\mathbf{F}$ & 60 & 150 & 59 & 1.54 & $\begin{array}{c}2.03 \\
(88)\end{array}$ & $\begin{array}{l}1.80 \\
(116)\end{array}$ & $\begin{array}{c}3.83 \\
(94)\end{array}$ & 182 & 66 & 3.2 & 96.2 & 97.5 \\
\hline 8 & $\mathrm{~F}$ & 63 & 175 & 60 & 1.72 & $\begin{array}{c}2.58 \\
(88)\end{array}$ & $\begin{array}{l}2.20 \\
(125)\end{array}$ & $\begin{array}{c}4.78 \\
(89)\end{array}$ & 157 & 77 & 5.8 & 95.4 & 95.3 \\
\hline 9 & $\mathbf{M}$ & 57 & 170 & 56 & 1.65 & $\begin{array}{c}3.96 \\
(99)\end{array}$ & $\begin{array}{c}3.02 \\
(111)\end{array}$ & $\begin{array}{l}6.98 \\
(108)\end{array}$ & 396 & 73 & 2.3 & 96.2 & 96.3 \\
\hline 10 & $\mathbf{M}$ & 61 & 170 & 59 & 1.68 & $\begin{array}{r}3.20 \\
(80)\end{array}$ & $\begin{array}{c}2.70 \\
(100)\end{array}$ & $\begin{array}{c}5.90 \\
(92)\end{array}$ & 125 & 62 & 2.0 & 96.9 & 95.1 \\
\hline
\end{tabular}

* VC is vital capacity; RV, residual volume; and TLC, total lung capacity. Values in parentheses are the percentages of predicted normal. $+\mathrm{MEFR}$ is maximal expiratory flow rate measured from 200 to $1,200 \mathrm{ml}$ of expired volume.

$\$ \mathrm{FEV}_{1.0} / \mathrm{FVC}$ is the forced expiratory volume at 1 second as a percentage of the forced vital capacity.

$\$ \mathrm{~N} 2$ elimination represents the result of the single-breath $\mathrm{N}_{2}$ elimination test. The figure for percentage of $\mathrm{N}_{2}$ is the concentration difference between 750 to $1,250 \mathrm{ml}$ expired gas after inspiration of $1 \mathrm{~L}$ of $\mathrm{O}_{2}$. Normal for this age group is 3.5 to $4.5 \%$ (19).

of the forced vital capacity) were measured with a 6-liter low-resistance spirometer. Distribution of ventilation was assessed with the single-breath $\mathrm{N}_{2}$ elimination test of Comroe and Fowler (20). $\mathrm{O}_{2}$ saturations were measured spectrophotometrically. Red cell mass was estimated by using $\mathrm{Co}^{51}$-labeled red cells, and plasma volume with $\mathrm{I}^{131}$-labeled albumin.

\section{RESULTS}

Preliminary lung function tests. Table I gives the details of patients and the results of pulmonary function tests. Vital capacity and total lung capacity were slightly below predicted normal in all patients and increased 10 to $15 \%$ after treatment. Residual volume was within normal limits in all before treatment and showed little change after. FEV 1.0, expressed as a percentage of forced vital capacity, was above $65 \%$ in all except $\mathrm{Pa}$ tient 10 , who had mild airways obstruction. The single-breath $\mathrm{N}_{2}$ elimination test was within the normal limits given by Sandqvist and Kjellmer (21), except in Patient 8, who had had a previous pulmonary infarction. The arterial $\mathrm{O}_{2}$ saturation at rest and on exercise was above $95 \%$ in all patients.

Hemoglobin and blood volume changes. Table
III gives the packed cell volume, hemoglobin concentration, blood volume, diffusion and dead space data, and A-a differences for $\mathrm{O}_{2}$ tension at the three stages of study. Blood volume data were not obtained for Patient 8 after venesection, and physiological dead space and A-a differences were not measured in Patient 7.

Packed cell volume was above $57 \%$ in all cases before treatment, with a correspondingly high hemoglobin concentration. Total blood volume was initially abnormally high, the mean $5,820 \mathrm{ml}$ being $117 \%$ of predicted normal $(22,23)$, mostly as a result of the increased red cell mass. After venesection, red cell mass decreased but plasma volume usually increased slightly, the result being a decrease in total circulating blood volume. The mean total blood volume after venesection was $5,480 \mathrm{ml}$ ( $107 \%$ of predicted) and after $\mathrm{P}^{32}$ it was $4,750 \mathrm{ml}$ ( $97 \%$ of predicted).

Changes in $D_{L}$. Table II gives individual mean values for $D_{L}$ at the three levels of alveolar $\mathrm{O}_{2}$ tension at each stage of the study. The mean of three determinations of $D_{L}$ in patients breathing air at each stage of the study is given in Table III and is expressed also as a percentage of the nor- 
TABLE II

Individual values for diffusing capacity and oxygen tension in pulmonary capillaries before and after treatment

\begin{tabular}{|c|c|c|c|c|c|c|c|}
\hline \multirow[b]{2}{*}{ Patient } & & \multicolumn{3}{|c|}{ Diffusing capacity } & \multicolumn{3}{|c|}{$\begin{array}{c}\begin{array}{c}\text { Mean } \mathrm{O}_{2} \text { ten- } \\
\text { sion in pul- } \\
\text { monary capillaries }\end{array} \\
\end{array}$} \\
\hline & & $\mathrm{a}^{*}$ & b & c & a & b & c \\
\hline \multirow{4}{*}{1} & & $m l / n$ & $n i n / m n$ & $n \mathrm{Hg}$ & & $m m H$ & \\
\hline & Untreated & 34.0 & 16.3 & 12.6 & 96 & 370 & 567 \\
\hline & After VS $\dagger$ & 24.0 & 14.3 & 10.6 & 87 & 323 & 531 \\
\hline & After Pzz & 23.6 & 15.1 & 12.9 & 133 & 385 & 576 \\
\hline \multirow[t]{3}{*}{2} & Untreated & 26.8 & 14.0 & 13.7 & 101 & 353 & 435 \\
\hline & After VS & 19.0 & 9.0 & 7.4 & 90 & 345 & 588 \\
\hline & After $\mathrm{P}^{32}$ & 24.3 & 13.5 & 10.3 & 137 & 361 & 568 \\
\hline \multirow[t]{2}{*}{3} & Untreated & 33.5 & 19.3 & 15.8 & 95 & 404 & 590 \\
\hline & After VS & 28.5 & 14.2 & 10.8 & 120 & 413 & 578 \\
\hline \multirow[t]{3}{*}{4} & Untreated & 28.5 & 14.6 & 13.8 & 98 & 345 & 469 \\
\hline & After VS & 23.1 & 9.1 & 7.1 & 84 & 400 & 555 \\
\hline & After $P^{32}$ & 15.4 & 6.3 & 3.5 & 87 & 281 & 505 \\
\hline \multirow[t]{3}{*}{5} & Untreated & 27.4 & 11.2 & 9.1 & 102 & 432 & 568 \\
\hline & After VS & 23.8 & 12.2 & 9.0 & 98 & 397 & 564 \\
\hline & After $\mathrm{P}^{32}$ & 27.2 & 12.5 & 10.8 & 130 & 404 & 595 \\
\hline \multirow[t]{3}{*}{6} & Untreated & 33.3 & 19.5 & 12.2 & 122 & 315 & 565 \\
\hline & After VS & 22.2 & 10.6 & 7.2 & 120 & 303 & 576 \\
\hline & After $P^{82}$ & 26.6 & 21.4 & 18.8 & 97 & 341 & 576 \\
\hline \multirow[t]{3}{*}{7} & Untreated & 40.4 & 25.0 & 18.3 & 92 & 373 & 542 \\
\hline & After VS & 27.3 & 16.5 & 12.3 & 92 & 360 & 545 \\
\hline & After $\mathrm{P} 82$ & 12.9 & 9.2 & 6.4 & 110 & 400 & 543 \\
\hline \multirow[t]{3}{*}{8} & Untreated & 23.6 & 17.0 & 10.0 & 102 & 234 & 554 \\
\hline & After VS & 15.3 & 8.9 & 5.6 & 95 & 260 & 515 \\
\hline & After $P^{32}$ & 8.2 & 5.9 & 3.3 & 110 & 337 & 511 \\
\hline \multirow[t]{3}{*}{9} & Untreated & 19.8 & 7.2 & 3.2 & 135 & 379 & 497 \\
\hline & After VS & 10.0 & 6.6 & 4.9 & 108 & 388 & 534 \\
\hline & After $P^{82}$ & 5.5 & 3.2 & & 95 & 297 & \\
\hline \multirow[t]{3}{*}{10} & Untreated & 20.0 & 11.7 & 9.8 & 130 & 328 & 537 \\
\hline & After VS & 9.0 & 4.1 & 2.5 & 110 & 283 & 516 \\
\hline & After Pa2 & 7.3 & 3.2 & & 105 & 310 & \\
\hline
\end{tabular}

$*_{\mathrm{a}}=$ Patient breathing air, test mixture containing $21 \% \mathrm{O}_{2} ; \mathrm{b}$ $=$ patient breathing air, test mixture containing $90 \% \mathrm{O}_{2}$; and $\mathrm{c}=$ 等

After VS = after venesection; after $\mathrm{P}^{32}=$ after treatment with $\mathrm{P}_{32}$

mal value predicted for that patient from the data of Burrows, Kasik, Niden, and Barclay (24). We did not have our own normal values in the appropriate age group, but in ten normal subjects, age 25 to 55 years, the measured values did not differ significantly from those predicted by the equation of Burrows and associates. The average standard deviation of the mean $D_{L}$, in the ten patients with polycythemia vera, when breathing air, was $1.4 \mathrm{ml}$ per minute per $\mathrm{mm} \mathrm{Hg}$. The coefficient of variation for all measurements of $D_{L}$ was $6.6 \%$.

Figure 1 gives $D_{L}$ as a percentage of predicted normal at the three stages of the study. Before treatment the value in all patients was greater than predicted. The mean value was $147 \%$ of the predicted value, a highly significant increase $(\mathrm{p}<0.01)$. After venesection, the mean value fell to $103 \%$ of predicted normal, five patients falling within the normal range, two above, and three probably below. After $\mathrm{P}^{32}$, the mean value was $81 \%$ of predicted normal; six patients were probably normal, but three were definitely subnormal.

Figure 2 shows $D_{L}$ at the different stages plotted against hemoglobin concentration at the time of study. $D_{L}$ decreased in every case after venesection, and this change was highly significant $(\mathrm{p}<$ 0.001 ). After $\mathrm{P}^{32}, D_{L}$ fell again, with a further decrease in hemoglobin concentration in most cases. In two cases hemoglobin increased, and $D_{L}$ returned towards its original value.

Changes in $\mathrm{D}_{L}$ at raised $\mathrm{O}_{2}$ tensions. The results presented in Table II show that $D_{L}$ at the intermediate and high $\mathrm{O}_{2}$ tensions decreased following venesection. The magnitude of the decrease was similar, $30 \%$ at the high $\mathrm{O}_{2}$ tension, $32 \%$ at the intermediate level, and $35 \%$ at the highest $\mathrm{O}_{2}$ tension.

The alveolar $\mathrm{O}_{2}$ tensions at which the measurements were made are also shown in Table II, and they show no obvious trend from one stage of the study to another.

Figure 3 shows an example of the way in which $D_{M}$ and $V c$ were determined from the values for $D_{L}$ measured at three levels of alveolar $\mathrm{O}_{2}$ tension. Since $D_{L}$ at the highest $\mathrm{O}_{2}$ tension was often small, especially following treatment, the reciprocal of

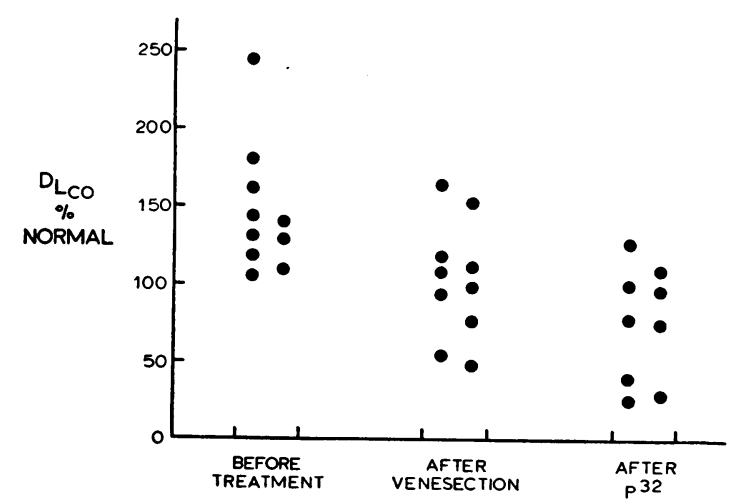

Fig. 1. Total PUlmonary diffusing CAPACITy For CO FROM THE ALVEOLUS TO THE INTERIOR OF THE RED CELL $\left(D_{\mathbf{L}}\right)$, EXPRESSED AS A PERCENTAGE OF NORMAL, BY USING THE PREDICTION FORMULA OF BURROWS AND ASSOCIATES (17), AT THE THREE STAGES OF STUDy. All estimates of $D_{\mathrm{L}}$ are the mean of three determinations. One patient died before study after $\mathrm{P}^{32}$. 
TABLE III

Blood volume and pulmonary diffusion measurements before and after treatment*

\begin{tabular}{|c|c|c|c|c|c|c|c|c|c|c|c|c|c|c|}
\hline Patient & & Date & $\mathrm{PCV}$ & $\mathrm{Hb}$ & $\underset{\text { volume }}{\mathrm{RBC}}$ & $\begin{array}{l}\text { Plasma } \\
\text { volume }\end{array}$ & $\begin{array}{c}\text { Total } \\
\text { blood } \\
\text { volumet }\end{array}$ & $V_{A}$ & $D_{L}$ & $D_{M}$ & $V c$ & $\begin{array}{l}\text { Cor- } \\
\text { rected } \\
V c_{+}^{+}\end{array}$ & $\begin{array}{l}V D / \\
V T \S\end{array}$ & $\mathrm{A}-\mathrm{aD} \S$ \\
\hline & & & $\%$ & $100 / \mathrm{ml}$ & $m l$ & $m l$ & $m l$ & $m l$ & $\underset{m m ~}{m l / m i n /}$ & $\begin{array}{c}\mathrm{ml} / \mathrm{min} / \\
\mathrm{mm} \mathrm{Hg}\end{array}$ & $m l$ & & $\%$ & $m m H g$ \\
\hline \multirow[t]{3}{*}{1} & a) & $5 / 9 / 61$ & 65 & 20.3 & 4,240 & 2,306 & $\begin{array}{l}6,546 \\
(101)\end{array}$ & 3,400 & $\begin{array}{l}34.0 \\
(139)\end{array}$ & 143 & 53 & 37 & $\begin{array}{c}24.3 \\
(26.3)\end{array}$ & $\begin{array}{c}17.4 \\
(11.2)\end{array}$ \\
\hline & b) & $5 / 17 / 61$ & 48 & 16.7 & 2,944 & 3,750 & $\begin{array}{l}6,694 \\
(104)\end{array}$ & 2,900 & $\begin{array}{r}24.0 \\
(99)\end{array}$ & 55 & 50 & 44 & 26.1 & $\begin{array}{l}35 \\
(15.4)\end{array}$ \\
\hline & c) & $2 / 1 / 62$ & 49 & 16.3 & 2,400 & 3,230 & $\begin{array}{r}5,630 \\
(87)\end{array}$ & 4,000 & $\begin{array}{c}23.6 \\
(97)\end{array}$ & 44 & 71 & 65 & 24.0 & $\begin{array}{c}7 \\
(16.1)\end{array}$ \\
\hline \multirow[t]{3}{*}{2} & a) & $5 / 13 / 61$ & 57 & 19.0 & 2,843 & 2,693 & $\begin{array}{r}5,536 \\
(94)\end{array}$ & 4,120 & $\begin{array}{l}26.8 \\
(133)\end{array}$ & 111 & 45 & 35 & $\begin{array}{c}34.2 \\
(28.3)\end{array}$ & $\begin{array}{c}24 \\
(17.0)\end{array}$ \\
\hline & b) & $5 / 19 / 61$ & 43 & 14.6 & 2,100 & 3,097 & $\begin{array}{r}5,197 \\
(88)\end{array}$ & 3,880 & $\begin{array}{c}19.0 \\
(95)\end{array}$ & 55 & 33 & 34 & 31.9 & $\stackrel{24}{(12.2)}$ \\
\hline & c) & $2 / 2 / 62$ & 54 & 18.5 & 2,446 & 2,274 & $\begin{array}{r}4,720 \\
(80)\end{array}$ & 4,300 & $\begin{array}{c}24.3 \\
(121)\end{array}$ & 166 & 42 & 34 & 31.0 & $\begin{array}{l}16 \\
(15.9)\end{array}$ \\
\hline \multirow[t]{2}{*}{3} & a) & $5 / 26 / 61$ & 61 & 18.3 & 3,317 & 2,631 & $\begin{array}{l}5,948 \\
(122)\end{array}$ & 4,930 & $\begin{array}{l}33.5 \\
(180)\end{array}$ & 66 & 85 & 68 & $\begin{array}{c}21.2 \\
(30.7)\end{array}$ & $\begin{array}{l}19 \\
(20.2)\end{array}$ \\
\hline & b) & $7 / 17 / 61$ & 52 & 15.6 & 2,600 & 3,200 & $\begin{array}{l}5,800 \\
(119)\end{array}$ & 5,200 & $\begin{array}{c}28.5 \\
(153)\end{array}$ & 143 & 47 & 45 & 27.3 & $\begin{array}{l}12 \\
(16.9)\end{array}$ \\
\hline \multirow[t]{3}{*}{4} & a) & $6 / 5 / 61$ & 64 & 19.4 & 3,592 & 2,852 & $\begin{array}{l}6,444 \\
(127)\end{array}$ & 4,350 & $\begin{array}{c}28.5 \\
(145)\end{array}$ & 77 & 51 & 41 & $\begin{array}{c}30.4 \\
(29.1)\end{array}$ & $\begin{array}{l}29 \\
(18.0)\end{array}$ \\
\hline & b) & $6 / 16 / 61$ & 42 & 12.0 & 2,623 & 3,250 & $\begin{array}{l}5,873 \\
(116)\end{array}$ & 3,900 & $\begin{array}{c}23.1 \\
(118)\end{array}$ & 1,000 & 27 & 34 & 28.8 & $\begin{array}{c}31 \\
(17.5)\end{array}$ \\
\hline & c) & $11 / 7 / 61$ & 42 & 13.3 & 1,841 & 3,623 & $\begin{array}{l}5,464 \\
(107)\end{array}$ & 4,000 & $\begin{array}{c}15.4 \\
(79)\end{array}$ & Infinite & 11 & 12 & & \\
\hline \multirow[t]{3}{*}{5} & a) & $6 / 13 / 61$ & 62 & 19.1 & 3,277 & 2,676 & $\begin{array}{l}5,953 \\
(132)\end{array}$ & 4,750 & $\begin{array}{c}27.4 \\
(128)\end{array}$ & 250 & 38 & 29 & $\begin{array}{l}16.4 \\
(23.1)\end{array}$ & $\stackrel{29}{(12.7)}$ \\
\hline & b) & $6 / 21 / 61$ & 45 & 12.0 & 2,381 & 3,200 & $\begin{array}{l}5,581 \\
(123)\end{array}$ & 4,800 & $\begin{array}{c}23.8 \\
(111)\end{array}$ & 87 & 40 & 40 & 20.5 & $\begin{array}{l}27 \\
(14.6)\end{array}$ \\
\hline & c) & $1 / 30 / 62$ & 46 & 16.1 & 1,954 & 2,398 & $\begin{array}{r}4,352 \\
(96)\end{array}$ & 4,600 & $\begin{array}{c}27.2 \\
(128)\end{array}$ & 143 & 46 & 42 & & \\
\hline \multirow[t]{3}{*}{6} & a) & $7 / 11 / 61$ & 58 & 17.0 & 4,037 & 3,178 & $\begin{array}{l}7,205 \\
(117)\end{array}$ & 4,350 & $\begin{array}{c}33.3 \\
(162)\end{array}$ & 250 & 51 & 40 & $\begin{array}{c}18.2 \\
(31.5)\end{array}$ & $\begin{array}{c}5 \\
(16.7)\end{array}$ \\
\hline & b) & $7 / 19 / 61$ & 48 & 15.3 & 2,840 & 3,400 & $\begin{array}{l}6,240 \\
(101)\end{array}$ & 4,370 & $\begin{array}{c}22.2 \\
(108)\end{array}$ & Infinite & 28 & 27 & 9.5 & $\stackrel{12}{(20.1)}$ \\
\hline & c) & $10 / 18 / 61$ & 40 & 12.7 & 1,571 & 2,419 & $\begin{array}{r}3,990 \\
(65)\end{array}$ & 4,790 & $\begin{array}{r}26.6 \\
(130)\end{array}$ & 35 & 160 & 168 & 6.9 & $\stackrel{17}{(22.8)}$ \\
\hline \multirow[t]{3}{*}{7} & a) & $10 / 20 / 61$ & 69 & 20.3 & 3,234 & 1,500 & $\begin{array}{l}4,734 \\
(124)\end{array}$ & 3,030 & $\begin{array}{l}40.4 \\
(245)\end{array}$ & 100 & 87 & 64 & & \\
\hline & b) & $11 / 1 / 61$ & 59 & 16.4 & 2,201 & 1,700 & $\begin{array}{l}3,901 \\
(102)\end{array}$ & 2,890 & $\begin{array}{c}27.3 \\
(165)\end{array}$ & 63 & 62 & 56 & & \\
\hline & c) & $3 / 8 / 62$ & 34 & 12.0 & 1,343 & 2,657 & $\begin{array}{l}4,000 \\
(104)\end{array}$ & 2,720 & $\begin{array}{c}12.9 \\
(78)\end{array}$ & 29 & 32 & 39 & & \\
\hline \multirow[t]{3}{*}{8} & a) & $10 / 27 / 61$ & 68 & 18.5 & 3,121 & 1.529 & $\begin{array}{l}4,650 \\
(120)\end{array}$ & 3,120 & $\begin{array}{l}23.6 \\
(119)\end{array}$ & 84 & 45 & 36 & $\begin{array}{c}24.2 \\
(30.3)\end{array}$ & $\begin{array}{c}23.3 \\
(19.7)\end{array}$ \\
\hline & b) & $11 / 14 / 61$ & 46 & 14.0 & & & & 3,270 & $\begin{array}{r}15.3 \\
(77)\end{array}$ & 72 & 21 & 23 & & \\
\hline & c) & $3 / 13 / 62$ & 42 & 13.2 & 2,337 & 3,163 & $\begin{array}{l}5,500 \\
(141)\end{array}$ & 3,120 & $\begin{array}{l}8.2 \\
(41)\end{array}$ & Infinite & 16 & 18 & & \\
\hline \multirow[t]{3}{*}{9} & a) & $12 / 19 / 61$ & 62 & 20.5 & 2,763 & 3,216 & $\begin{array}{l}4,979 \\
(109)\end{array}$ & 4,870 & $\begin{array}{c}19.8 \\
(106)\end{array}$ & Infinite & 15 & 11 & $\begin{array}{c}34.6 \\
(28.1)\end{array}$ & $\begin{array}{c}25.6 \\
(16.2)\end{array}$ \\
\hline & b) & $1 / 1 / 62$ & 46 & 14.2 & 1.735 & 2,500 & $\begin{array}{r}4,235 \\
(92)\end{array}$ & 5,190 & $\begin{array}{r}10.0 \\
(54)\end{array}$ & 31 & 22 & 23 & 45.2 & $\begin{array}{c}8.2 \\
(14.7)\end{array}$ \\
\hline & c) & $5 / 7 / 62$ & 52 & 13.6 & 1,526 & 2,036 & $\begin{array}{r}3,562 \\
-\quad(78)\end{array}$ & 4,890 & $\begin{array}{l}5.5 \\
(29)\end{array}$ & Infinite & 10 & 11 & 46.5 & $\begin{array}{c}14.2 \\
(14.8)\end{array}$ \\
\hline \multirow[t]{3}{*}{10} & a) & $1 / 25 / 62$ & 71 & 20.6 & 3,900 & 2,255 & $\begin{array}{l}6,155 \\
(126)\end{array}$ & 4,560 & $\begin{array}{c}20.0 \\
(109)\end{array}$ & 55 & 44 & 32 & $\begin{array}{c}40.0 \\
(29.5)\end{array}$ & $\begin{array}{l}37 \\
(19.1)\end{array}$ \\
\hline & b) & $2 / 5 / 62$ & 48 & 14.2 & 2,741 & 3,080 & $\begin{array}{l}5,821 \\
(119)\end{array}$ & 4,450 & $\begin{array}{c}9.0 \\
(49)\end{array}$ & Infinite & 8 & 9 & 34.7 & $\begin{array}{l}42 \\
(17.4)\end{array}$ \\
\hline & c) & $5 / 8 / 62$ & 40 & 12.3 & 2,043 & 3,466 & $\begin{array}{l}5,509 \\
(113)\end{array}$ & 4,470 & $\begin{array}{c}7.3 \\
(27)\end{array}$ & Infinite & 5 & 6 & 38.5 & $\begin{array}{c}30.5 \\
(16.5)\end{array}$ \\
\hline
\end{tabular}

* Table gives data at three states of study; a) before treatment; b) after venesection 1 week later; and c) after P32 at least 3 months later. $P C V=$ packed cell volume; $V_{A}=$ mean alveolar volume; $D_{L}=$ total pulmonary diffusing capacity when breathing air; $D_{M}=$ membrane dif fusing capacity; $V c=$ pulmonary capillary blood volume; $V_{D} / V_{T}=$ ratio of physiological dead space to tidal volume when breathing air; an

$\mathrm{A}-\mathrm{aD}=$ difference in oxygen tension between alveolar gas and arterial blood when breathing air.

Corrected $V c$ was obtained by multiplying calculated $V c$ by $20 / \mathrm{O}_{2}$ capacity (16).

$\$$ Values in parentheses below $V_{D} / V_{T}$ and $\mathrm{A}-\mathrm{aD}$ are predicted mean normal values (17). 


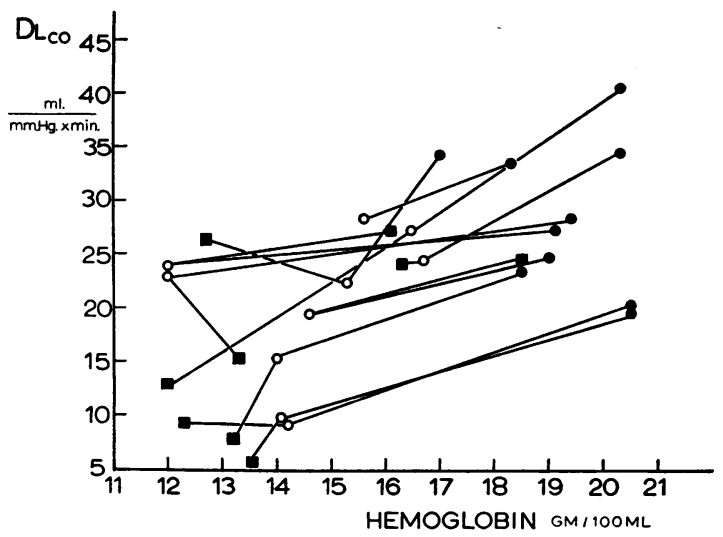

Fig. 2. The Diffusing CAPACITY of The LUNG $\left(D_{\mathbf{L}}\right)$ PLOTTED AGAINST HEMOGLOBIN CONCENTRATION IN GRAMS PER 100 ML AT THE TIME OF STUDY. The black circles are before treatment, the open circles 1 week later after venesection, and the black squares 3 months after $P^{32}$. All points are the means of three determinations of $D_{L}$.

the individual values sometimes varied more than shown in this example, and the line of best fit was then less readily constructed.

Changes in $D_{M}$. It can be seen from Table III that the values for $D_{M}$ were very variable. This is in keeping with our experience in normal subjects, in one of whom $D_{M}$ ranged from 50 to 153 in eight measurements over a 10 -month period. There was no systematic change from one stage of the present study to another.

Changes in $V c$. The individual values for $V c$, both uncorrected and after correction for hemoglobin concentration, are shown in Table III. Comparison has been made with the results of Hamer (25), who found a mean of $74.5 \mathrm{ml}$ (SD, $32.2)$ in 25 normal subjects and no change in $V c$ with age. These agreed well with our finding of a mean $V c$ of $75.0 \mathrm{ml}$ in six normal subjects whose average age was 30 years.

The uncorrected $V c$ in the untreated patients had a mean value of $51.4 \mathrm{ml}$, which was not significantly less than normal $(0.05<\mathrm{p}<0.1)$. After venesection there was a significant fall ( $p<$ 0.01 ), but there was no further change following treatment with $\mathrm{P}^{32}$.

The mean $V c$ after correction for hemoglobin concentration was $39.3 \mathrm{ml}$, which was significantly less than normal $(\mathrm{p}<0.01)$. In each patient the value was less than the mean normal value. Neither after venesection nor treatment with $\mathrm{P}^{32}$ was there any significant change in corrected $V c$.
It will be noted that the three patients who had a definitely subnormal $D_{L}$ after treatment (Patients 8,9, and 10) also had the lowest values for corrected $V c(6,11$, and $18 \mathrm{ml}$, respectively). These patients were slightly anemic at the time of measurement, but the degree of anemia does not appear sufficient to explain the very low $D_{L}$.

Physiological dead space and $A$-a difference. The results obtained for the ratio $V_{D} / V_{T}$ (physiological dead space to tidal volume) and A-a difference in patients breathing air are given in Table III. The value for A-a difference tended to be higher than normal, but was definitely above the normal range in only two patients before treatment. It remained abnormal after treatment in one of these (Patient 10, who had mild chronic bronchitis). Alveolar-arterial difference did not correlate with $D_{L}$, and there was no definite trend in the former with treatment. $V_{D}$ expressed as a percentage of $V_{T}$ was within normal limits in all patients except Patients 9 and 10. It was not measured in Patient 7 and only in the first stage in Patient 8. These high values for $V_{D}$ were associated with the two lowest values for $V c$.

\section{DISCUSSION}

The present results indicate that, as predicted, $D_{L}$ was greater than normal in the group of patients with polycythemia vera before treatment. They differ from the results of most other workers, who have concluded that $D_{L}$ was normal in

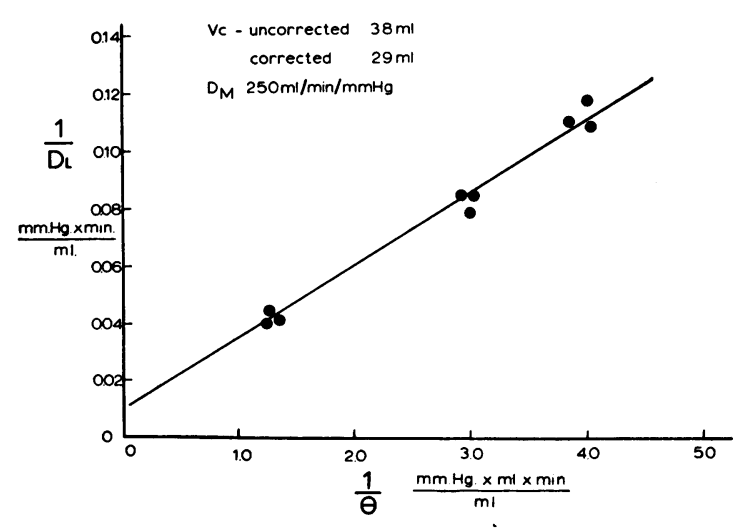

Fig. 3. Example of the Relationship Between $1 / D_{L}$ and $1 / \theta$ (Patient 5 , Before treatment). $D_{\mathrm{L}}$ is the total pulmonary diffusing capacity for $\mathrm{CO}$ from the alveolus to the interior of the red cell; $\theta$ is the product of the rate at which $\mathrm{CO}$ replaces $\mathrm{O}_{2}$ in oxyhemoglobin and the concentration of hemoglobin. 
this disease $(5,6,8)$. One possible reason for this may lie in the rather wide range of $D_{L}$ in normal subjects (24), which makes it difficult to state with certainty that a value for an individual is outside the normal limits. This difficulty was partly avoided in the present study by comparison of results before and after treatment.

The low results for $D_{L}$ reported by Harrop and Heath (4) are more difficult to explain. Forster (7) has suggested that some of their patients were cases of secondary polycythemia, but as all were said to have had a palpable spleen, this explanation seems unlikely. They made no allowance for back pressure, however, which would have caused the results to be falsely low.

$D_{L}$ invariably decreased after treatment in the patients with polycythemia vera. In five patients the value after treatment was normal, but in $\mathrm{Pa}$ tients $4,7,8,9$, and 10 it was abnormally low. In three of these $D_{L}$ before treatment had been only a little greater than normal. In all of the patients in whom $D_{L}$ was abnormally low after treatment, the $V c$ was also less than normal.

It appears most probable that the increased $D_{L}$ before treatment resulted from the increased hemoglobin concentration of the blood in those capillaries taking part in gas exchange in the lung. The $V c$, when corrected for hemoglobin concentration, was less than normal and there is no evidence that $D_{M}$ was increased. Although the precision of estimates of $D_{M}$ is poor, the measurements of $V c$ are more reliable. Even when we accept the inaccuracy of the estimates of $D_{M}$, consideration of the number and shape of capillaries still makes it hardly possible for $D_{M}$ to have been greater than normal, when corrected $V c$ was significantly less than normal. Furthermore, the changes in $D_{L}$ following treatment are also explicable by the alteration in hemoglobin concentration; in only two instances did a change in $D_{L}$ fail to follow the change in hemoglobin concentration. These changes in $D_{L}$ are the converse of those reported by Rankin and associates (2) in anemia before and after treatment. They concluded that the change in $D_{L}$ was due solely to a change in $\theta$, and they found that $V c$ did not alter after treatment when this was allowed for.

$V c$ when corrected for hemoglobin concentration was significantly less than normal, and individual patients showed very low values. This is of interest, since the total blood volume was greatly increased. The radiological appearances suggested that the major pulmonary arteries and veins were distended, and these changes disappeared after treatment. In a group of seven other patients with polycythemia vera, Segel (26) measured the "central blood volume" by injection of $\mathrm{I}^{131}$-labeled human serum albumin into the pulmonary artery. The mean value before treatment was $1,341 \mathrm{ml}$, which is greater than normal. In each patient there was a decrease following treatment, the mean then being $949 \mathrm{ml}$, and the change was highly significant $(p<0.001)$. The pulmonary capillary bed does not therefore share in the pulmonary vascular engorgement of this disease, and treatment had no significant effect upon $V c$.

The values for $D_{M}$ are even more variable than those previously found in normal subjects. Forster (7) has emphasized that $D_{M}$ is a less reliable measurement than $V c$, as it is more affected by small errors in $D_{L}$. This is especially true in the present series where $D_{L}$ is low in several cases and therefore less exact. It can also be seen from the graphical solution of Equation 1 that when $V c$ is small, the slope of the line is steep, and therefore the intercept less reliable. $D_{M}$ is also dependent on the value used for $\lambda$ (the ratio of the permeability of the red cell membrane to that of the red cell interior). Lacking conclusive evidence of the true value, most workers at present use 2.5 , as we have done. If we had taken $\lambda=\propto$ or $\lambda=1.5$, all the values for $D_{M}$ would have been decreased or increased, but the variability between them would remain. In view of these difficulties, no conclusions can be drawn from changes in $D_{M}$ in this study.

In seeking an explanation for the reduction of $V c$, it is first necessary to consider whether the measurements are valid. It has been assumed, as must always be done in estimating $V c$ by this method, that the pulmonary capillary hematocrit is equal to the venous hematocrit. This assumption is usually thought to be justifiable in healthy subjects, and there does not appear to be any further reason to doubt its validity in polycythemia. After treatment, these patients had blood of a normal composition, and $V c$ was still abnormally small in several of them. A further objection might be raised to the use of values for $\theta$ obtained from normal blood. It is true that $\theta$ has 


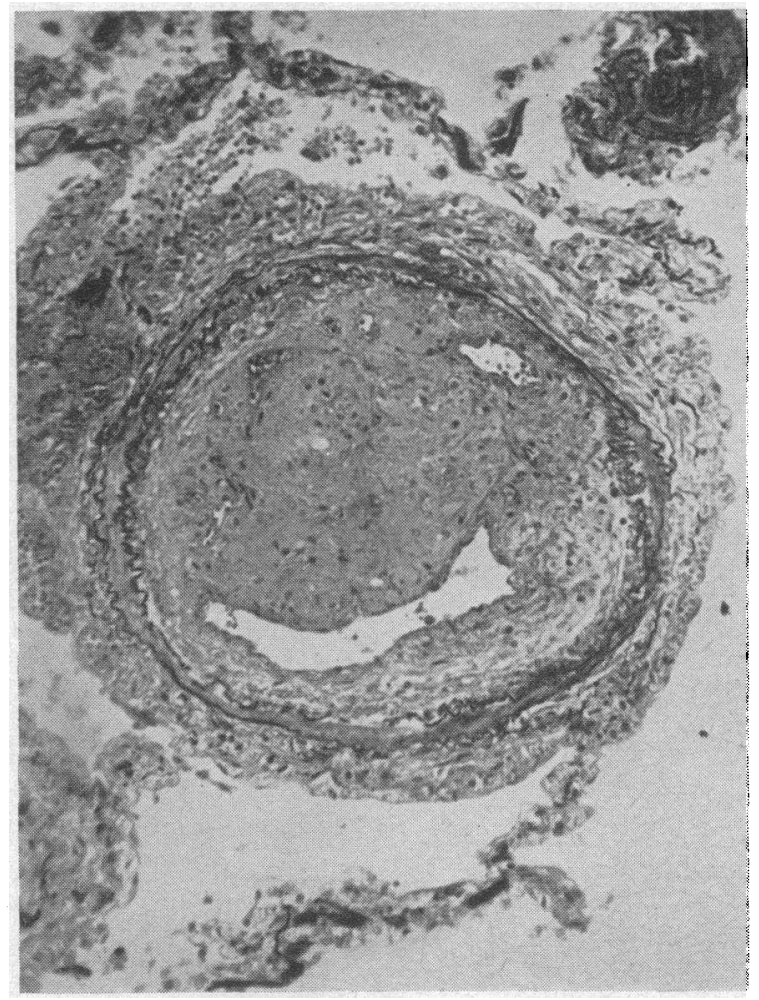

Fig. 4. Transverse section through a small pUlMONARY ARTERY SHOWING AN ABNORMALLY THIN MEDIA WITH ATROPHY OF ELASTIC FIBERS. There is a large recent thrombus and below, a crescent of old organized thrombus; $\times 150$. Elastic, Van Gieson stain.

not been determined for blood from polycythemic patients, but the red cells in this disease appear normal in size and shape, and the hemoglobin concentration within them is normal. It therefor seems unlikely that their rate of gas uptake will differ appreciably from normal.

Consequently, the reduction of $V c$ is a real one, and the evidence suggests a possible explanation. It is well known that patients with polycythemia are especially prone to both arterial and venous thrombosis in the systemic circulation. They not uncommonly also suffer pulmonary infarcts, although only one of the patients studied was known to have done so. It is suggested that widespread thrombosis in small pulmonary arteries may occur, leading to a substantial obliteration of the pulmonary capillary bed, without giving rise to clinically obvious pulmonary infarction.

We have not been able to find reports of histological examination of the lungs in this disease, nor have we had the opportunity of examining the lungs of any of the patients we have studied. We have, with the help of Dr. Donald Heath, studied sections of lung taken from two other patients who had died with polycythemia vera. In both, there was evidence of thrombus formation in many small pulmonary arteries, and in one case, large pulmonary arteries as well. The pulmonary veins were not affected, but thrombus was also present in bronchial arteries. The appearances in one patient are illustrated in Figures 4 and 5.

Additional evidence in favor of such an explanation is that indicating a disturbance of ventilation perfusion ratios in the lung. The A-a difference when the patients breathed air tended to be larger than normal, as also did the ratio $V_{D} / V_{T}$. The latter was definitely abnormal in the two patients with the smallest $V c$. These patients had normally distributed ventilation as judged by the single-breath oxygen test, and the finding of a larger than normal $V_{D}$ therefore suggests the presence of relatively underperfused alveoli.

The spleen was enlarged in all but one of the patients studied, and all fulfilled the other clinical and hematologic criteria for the diagnosis of polycythemia vera. From this point of view they were a homogeneous group. The considerable variability in $D_{L}$ was an unexpected finding, and the possibility was considered that in some patients the impairment of gas exchange had caused a secondary polycythemia. Such an occurrence is very unusual in patients with a similar reduc-

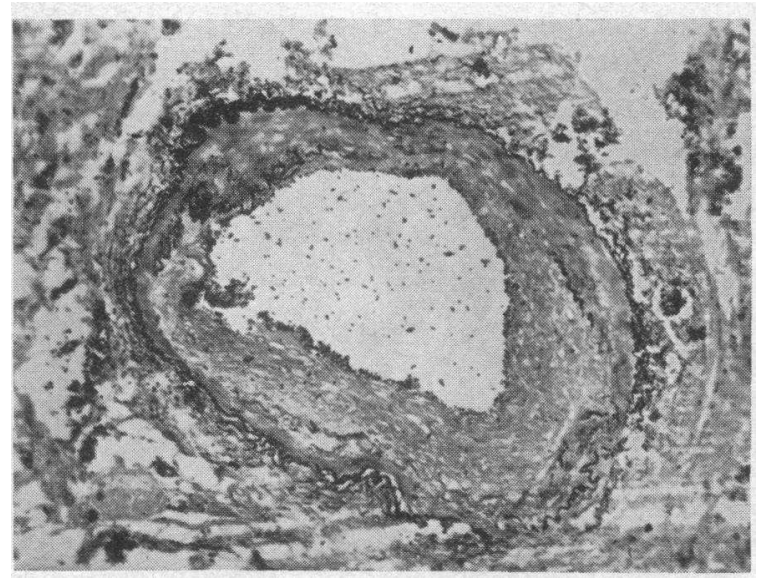

Fig. 5. Transverse section through a bronchial ARTERY SHOWING DESTRUCTION OF THE INTERNAL ELASTIC LAMINA, WIDESPREAD ATROPHY OF THE MEDIA, AND AN EXTENSIVE ORGANIZED THROMBUS; $\times 100$. Elastic, Van Gieson stain. 
tion of $D_{L}$, due to the alveolar-capillary block syndrome, and even then the polycythemia is only slight. Furthermore, none of our patients had arterial unsaturation at rest or during exercise before (Table III) or after treatment. It is therefore concluded that the reduced $D_{L}$ was not the cause of the polycythemia.

These data reinforce the view that hemoglobin concentrations cannot be ignored in the assessment of $D_{L}$, as measured at present. It has previously been shown that patients with severe anemia have a low $D_{L}(2)$, and the present study indicates that the reverse is true in polycythemia vera. It remains uncertain, however, whether smaller deviations of hemoglobin from normal will significantly affect determinations of $D_{L}$ for clinical purposes.

\section{SUMMARY}

Pulmonary diffusing capacity $\left(D_{L}\right)$, membrane diffusing capacity $\left(D_{M}\right)$, and pulmonary capillary blood volume $(V c)$ were estimated by a single-breath carbon monoxide method in ten patients with polycythemia vera before and after treatment.

$D_{L}$ was greater than normal in all patients before treatment; after treatment it was normal or below normal. In the latter cases, $V c$ was very small, and physiological dead space $\left(V_{D}\right)$ was sometimes increased.

$V c$, corrected for hemoglobin concentration, was less than normal and did not change significantly after treatment. $D_{M}$ varied widely both before and after treatment.

It is suggested that the increased $D_{L}$ before treatment resulted from the increased hemoglobin concentration, and it is postulated that the reduction of $V c$ may have been due to thrombosis of small pulmonary arteries.

\section{ACKNOWLEDGMENTS}

We are much indebted to Dr. Nathan Segel, who is studying the hemodynamic effects of polycythemia vera, for the measurements of blood volume and to Dr. Donald Heath for advice about the histology of the pulmonary vessels.

\section{REFERENCES}

1. Roughton, F. J. W., and R. E. Forster. Relative importance of diffusion and chemical reaction rates in determining rate of exchange of gases in the human lung, with special reference to true diffusing capacity of pulmonary membrane and volume of blood in the lung capillaries. J. appl. Physiol. 1957, 11, 290.

2. Rankin, J., R. S. McNeill, and R. E. Forster. The effect of anemia on the alveolar-capillary exchange of carbon monoxide in man. J. clin. Invest. 1961, 40, 1323

3. McNeill, R. S., J. Rankin, and R. E. Forster. The diffusing capacity of the pulmonary membrane and the pulmonary capillary blood volume in cardiopulmonary disease. Clin. Sci. 1958, 17, 465.

4. Harrop, G. A., Jr., and E. H. Heath. Pulmonary gas diffusion in polycythemia vera. J. clin. Invest. 1927, 4, 53.

5. Ratto, O., W. A. Briscoe, J. W. Morton, and J. H. Comroe, Jr. Anoxemia secondary to polycythemia and polycythemia secondary to anoxemia. Amer. J. Med. 1955, 19, 958.

6. Rankin, J., R. S. McNeill, and R. E. Forster. Diffusion characteristics of the pulmonary membrane and capillary bed in various diseases of the lungs and cardio-vascular system (abstract). J. clin. Invest. 1957, 36, 922.

7. Forster, R. E. Exchange of gases between alveolar air and pulmonary capillary blood: Pulmonary diffusing capacity. Physiol. Rev. 1957, 37, 391.

8. Fishman, A. P. in Polycythemia, Report of the Combined Staff Clinic of Presbyterian Hospital, R. J. Cross, Ed. Amer. J. Med. 1958, 24, 132.

9. Newman, W., J. A. Feltman, and B. Devlin. Pulmonary function studies in polycythemia vera. Results in five probable cases. Amer. J. Med. 1951, 11, 706.

10. Lawrence, J. H., R. L. Huff, W. Siri, L. R. Wasserman, and T. G. Hennessey. A physiological study in the Peruvian Andes. Acta med. scand. 1952, 142, 117.

11. Barcroft, J., C. A. Binger, A. V. Bock, J. H. Doggart, H. S. Forbes, G. Harrop, J. C. Meakins, and A. C. Redfield. Observations upon the effect of high altitude on physiological processes in the human body carried out in the Peruvian Andes, chiefly at Cerro de Pasco. Phil. Trans. B 1921, 211, 351.

12. Houston, C. S., and R. L. Riley. Respiratory and circulatory changes during acclimatization to high altitude. Amer. J. Physiol. 1947, 149, 565.

13. Velasquez, T. Maximal diffusing capacity of the lungs at high altitudes. School of Aviation Medicine, U.S.A.F. report no. 56-108, 1956.

14. Ogilvie, C. M., R. E. Forster, W. S. Blakemore, and J. W. Morton. A standardized breath holding technique for the clinical measurement of the diffusing capacity of the lung for carbon monoxide. J. clin. Invest. 1957, 36, 1.

15. Jones, R. S., and F. Meade. A theoretical and experimental analysis of anomalies in the estima- 
tion of pulmonary diffusing capacity by the single breath method. Quart. J. exp. Physiol. 1961, 46, 131.

16. Gilson, J. C., and P. Hugh-Jones. The measurement of the total lung volume and breathing capacity. Clin. Sci. 1948, 7, 185.

17. Bishop, J. M. Measurement of blood oxygen tension. Proc. roy. Soc. Med. 1960, 53, 177.

18. Stein, M., P. Kimbel, and R. L. Johnson, Jr. Pulmonary function in hyperthyroidism. J. clin. Invest. 1961, 40, 348.

19. Raine, J. M., and J. M. Bishop. A-a difference in $\mathrm{O}_{2}$ tension and physiological dead space in normal man. J. appl. Physiol. 1963, 18, 284.

20. Comroe, J. H., Jr., and W. S. Fowler. Lung function studies. VI. Detection of uneven alveolar ventilation during a single breath of oxygen. Amer. J. Med. 1951, 10, 408.
21. Sandqvist, S., and I. Kjellmer. Normal values for the single breath nitrogen elimination test in different age groups. Scand. J. clin. Lab. Invest. $1960,12,131$.

22. Gregerson, M. I., and J. L. Nickerson. Relation of blood volume and cardiac output to body type. J. appl. Physiol. 1950, 3, 329.

23. Sjöstrand, T. Volume and distribution of blood and their significance in regulating the circulation. Physiol. Rev. 1953, 33, 202.

24. Burrows, B., J. E. Kasik, A. H. Niden, and W. R. Barclay. Clinical usefulness of the single-breath pulmonary diffusing capacity test. Amer. Rev. resp. Dis. 1961, 84, 789.

25. Hamer, N. A. J. The effect of age on the components of the pulmonary diffusing capacity. Clin. Sci. 1962, 23, 85.

26. Segel, N. Personal communication.

\section{SPECIAL NOTICE TO SUBSCRIBERS}

Post Offices will no longer forward the Journal when you move.

Please notify The Journal of Clinical Investigation, Business Office, 10 Stoughton Street, Boston 18, Mass., at once when you have a change of address, and do not omit the zone number if there is one. 